
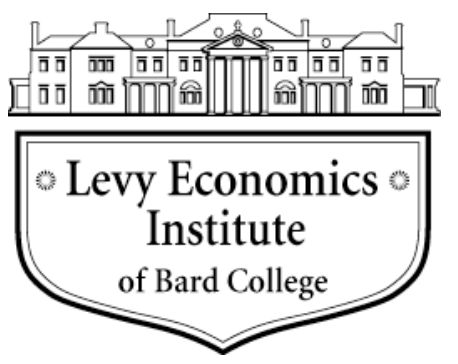

Working Paper No. 678

\title{
What Ended the Great Depression? Reevaluating the Role of Fiscal Policy
}

by

\author{
Nathan Perry \\ Mesa State College \\ Matías Vernengo \\ University of Utah
}

July 2011

The Levy Economics Institute Working Paper Collection presents research in progress by Levy Institute scholars and conference participants. The purpose of the series is to disseminate ideas to and elicit comments from academics and professionals.

Levy Economics Institute of Bard College, founded in 1986, is a nonprofit, nonpartisan, independently funded research organization devoted to public service. Through scholarship and economic research it generates viable, effective public policy responses to important economic problems that profoundly affect the quality of life in the United States and abroad.

Levy Economics Institute P.O. Box 5000

Annandale-on-Hudson, NY 12504-5000

http://www.levyinstitute.org 


\begin{abstract}
Conventional wisdom contends that fiscal policy was of secondary importance to the economic recovery in the 1930s. The recovery is then connected to monetary policy that allowed non-sterilized gold inflows to increase the money supply. Often, this is shown by measuring the fiscal multipliers, and demonstrating that they were relatively small.

This paper shows that problems with the conventional measures of fiscal multipliers in the 1930s may have created an incorrect consensus on the irrelevance of fiscal policy. The rehabilitation of fiscal policy is seen as a necessary step in the reinterpretation of the positive role of New Deal policies for the recovery.
\end{abstract}

Keywords: Fiscal Policy; Great Depression

JEL Classifications: E62, E63, N12 


\section{INTRODUCTION}

The established conventional wisdom on the causes of the Great Depression emphasizes the role of restrictive monetary and fiscal policies implemented as a result of the Gold Standard (Eichengreen 1992). In particular, it is argued that monetary contraction (Friedman \& Schwartz 1963) and banking panic (Bernanke 1983) in the United States were the initial shocks that caused the crisis that was propagated to the rest of the world by the international monetary system (Temin 1989).

Temin (1989) following Kindleberger (1973), suggests that the causes of the Depression are more profound. In this view, strong policy action to deal with a major international financial crisis is extremely unlikely in the absence of a hegemon-i.e. a dominant economic power that has the international reserve currency and can provide liquidity and expanding demand in the case of a crisis. World War I, the collapse of British hegemonic power, and the unwillingness of the United States to step into the hegemonic role vacated by the United Kingdom are the deeper causes of the Great Depression.

If the Gold Standard is central for understanding the causes of the Great Depression, then recovery, by the same token, would be associated with the abandonment of that particular international monetary arrangement. Eichengreen \& Sachs (1985) show that the countries that depreciated first were the first to recover, supporting the view that the Gold Standard was to blame for the depth of the global slump. ${ }^{1}$

Friedman \& Schwartz (1963), on the other hand, argue that the increase in money supply from 1933 onwards spearheaded the recovery. Romer (1992) suggests that monetary policy indeed was central for the recovery, more so than fiscal policy and that the main cause of the monetary expansion was the gold inflows associated with the European political instability. ${ }^{2}$ Fiscal policy and the employment creation policies of the New Deal are, in this approach, of secondary importance. ${ }^{3}$

\footnotetext{
1 Diaz Alejandro (1984) provides similar evidence for Latin American countries.

2 Similar argument is put forward by Meltzer (2003).

3 The classic paper by E. Cary Brown (1956) is the seminal work that suggests that fiscal policy was insufficient during the 1930s to get the economy out of the prolonged slump.
} 
This paper analyzes the evidence presented by Romer (1992) on the role of fiscal policy. The paper suggests that the role of fiscal policy has been misrepresented in the conventional literature, and that in fact fiscal policy was central for the recovery. The next section discusses the problems with the conventional interpretation and the role of monetary policy during the recovery. The following section describes the limitations of Romer's approach to the analysis of fiscal policy, while the subsequent presents an alternative interpretation of the recovery in which fiscal policy is shown to have a prominent role. The last section presents some concluding remarks on the current reinterpretations of the New Deal.

\section{PUSHING ON A STRING DOESN'T DO IT FOR ME}

Conventional interpretations of the causes of the Great Depression and the subsequent recovery tend to emphasize monetary factors, in particular, those associated with the functioning of the international monetary system. The limitations of the inter-war Gold Standard are central for the conventional wisdom on the depression. These views are fundamentally based on a variation of Hume's price-specie flow mechanism, according to which flows of gold, and their effects on prices would lead to a smooth adjustment of the balance of payments (Eichengreen 1996). ${ }^{4}$

In this view, the gold standard failed because of lack of credibility, partly caused by the political pressures associated with the rise of the masses, and their political role in undermining the government's commitment to price stability. Hence, gold outflows generated the deflationary pressures, and caused the fall in the level of output and employment.

However, gold stocks are correlated with domestic money supply measures, and with the level of activity, falling mildly in the beginning of the depression-with a few fluctuations in 1930 and 1931, following international events, including Britain's move off gold in September of the latter year-and a significant increase after 1934, even after

\footnotetext{
${ }^{4}$ Eichengreen (1996, p. 25) argues, in fact, that Hume's theory "remains the dominant approach to thinking about the gold standard today." In fact, a modern version based on the incorporation of rational expectations, and time inconsistency can be seen as a modern version of the specie flow model (Bordo and Kydland 1996).
} 
the depreciation of the dollar in April 1933. However, the correlation between gold, output and prices is weak, and as noted by Meltzer (2003, p. 275), the gold standard had not prevented anti-cyclical policies in the 1923-24 and 1926-27 recessions. In other words, the Fed would have had space to expand the money supply and avoid the contraction that led to deflation and the depression, even within the rules of the Gold Standard system. The policies of the Fed, rather than the Gold Standard, in the monetarist view are to blame for the Great Depression. ${ }^{5}$

This is why Meltzer (2003) characterizes monetary policy as a failure in the 192933 recession, and as taking the back seat rather than the steering wheel in the 1933-37 recovery, even though monetary policy is seen as central for the recovery. The money supply, in monetarist fashion, led the recovery, but the Fed was a passive observer of the outflows and inflows of specie.

Meltzer's argument is that the severity of the monetary contraction was, to a great extent, the result of adherence by monetary authorities to the real bills doctrine, and not simply a result of the gold standard rules. Like Friedman \& Schwartz (1963), Meltzer argues that it was the failure of the monetary authorities that caused the depression.

In both views, either the conventional view that attributes the monetary contraction to the Gold Standard (e.g. Eichengreen 1992) and the monetarist view (e.g. Meltzer, 2003) the causality goes from money to prices and output. The monetary contraction would have not caused the recession if prices adjusted quickly enough, but the nominal rigidities imply the need for quantity adjustments as well. The nominal rigidity argument is the reason why these are sometimes seen as Keynesian

\footnotetext{
${ }^{5}$ From a theoretical point of view, Meltzer (2003, p. 63) distinguishes between what he refers to as the Ricardian tradition, associated also with the Bullionists and the Currency School, that believed in a strict correlation between gold and prices, with the works of Thornton, Fisher, and Keynes of the Treatise on Money (Wicksell is surprisingly excluded), that allowed for output variations and lagged effects on prices. He dismisses the defenders of the Real Bills Doctrine, in which he includes Steuart but not Smith, and the Banking School, and presumably the modern defenders of endogenous money (which are not cited) as lacking a coherent analytical framework. For Meltzer the Banking School argument boils down simply to a belief that monetary policy is impossible or inefficient. For that reason, perhaps, Meltzer (2003, p. 21) tends to believe that the distinctions between monetary schools "suggest more direct confrontation of ideas than appears to have taken place." In fact, at the heart of the Bullionist/Anti-Bullionist, Currency/Banking school debates there is a central methodological issue, that is, the causality between money, prices, and output.
} 
interpretations of the depression. ${ }^{6}$ In both views, monetary policy is sufficient for bringing the system back to equilibrium, and a moderate amount of fiscal policy is only necessary as a result of the short-term rigidities.

Once the money or banking rate of interest is aligned with the natural rate of interest, the system would return to full employment. ${ }^{7}$ The problem with the conventional interpretation is that it is not sufficient to dismiss the alternative approach, which suggests reverse causality between money, prices, and output. In this view, a collapse of spending (e.g. consumption), caused in part by the collapse of a bubble (i.e. asset price deflation) would reduce the level of economic activity, and the demand for money. A central bank that followed the Real Bills Doctrine as the Fed did would reduce the money supply, but would not be responsible for the collapse in output or the deflation, even if it were responsible for preventing the bubble in the first place. ${ }^{8}$ In other words, money supply increase is neither sufficient nor necessary for economic recovery.

This is not to say that the money supply is unrelated to the recovery. The identity of exchange implies that by definition the uses of money match the nominal value of output. As a result, it is always possible that a recovery would depend on an increasing velocity of circulation of money, and actual recoveries tend to rely both on increasing money supply and increased velocity of circulation. But recoveries also rely on the expansion of spending (in general a combination of private and public spending), low rates of interest, the expansion of credit and, in the case of the Great Depression, a more depreciated exchange rate. One may conclude that an increase in money supply is an insufficient but non-redundant part of the unnecessary but sufficient conditions for

\footnotetext{
${ }^{6}$ Meltzer (2003, p. 55) is, for example, critical of the rational expectations school for assuming that the price level responds to money instantaneously.

${ }^{7}$ The only additional problem would be the zero bound limit to the nominal rate of interest, and the lack of understanding by the monetary authorities of the distinction between real and nominal variables, something emphasized by Meltzer (2003, p. 53), since in this case deflation would imply high real rates even if the nominal rates of interest are low. This lack of understanding is only a problem if the monetary authority can actually produce inflation by increasing the money supply, something that is taken for granted by Meltzer, a view also assumed by Christiano et al. (2003).

${ }^{8}$ Note that in this approach there is no need for nominal rigidities to cause the recession, a view more akin to that of Keynes in the General Theory, who believed that price flexibility would make things worse rather than better (Amadeo 1989).
} 
recovery. ${ }^{9}$ In other words, the increase in money supply is only one of the several elements needed for economic recovery.

It is possible, in this context, that the recovery and the increase in money supply are the effects of a third causal force. The post-Keynesian view of the recovery would, in fact, emphasize the role of spending, and the endogenous nature of money supply. In this view, faced with a contracting economy and deflation, monetary policy can only reduce the nominal rate of interest to its lower bound, and expect that it would stimulate spending. The famous phrase, incorrectly attributed to, but popularized by Marriner Eccles, the Fed's chairman in that period, that monetary policy in a depression was like "pushing on a string" fits this view on the causality between monetary and real variables. $^{10}$

Also, it is important to note that a central aspect of the monetary policy of a central bank that follows the Real Bills Doctrine is to function as the fiscal agent of the State. The central bank not only provides the money supply according to the needs of trade, but also guarantees the credit of the central government, maintaining relatively low rates of interest on government debt. In other words, not only the short-term rate of interest is kept low, but also the long-term rate. In order to maintain this policy, the Fed has to buy government bonds whenever the private demand is not sufficiently large, this is also known as quantitative easing.

After the 1929 crisis the amount of government securities rose from less than 10 percent of total assets held by the Fed to more than 30 percent, and as the economy recovered the volume fell to almost the initial levels, only to take off during World War II. The objective of quantitative easing was to maintain the rate of interest on government bonds below 2.5 percent, an objective that was acknowledged by the Fed authorities, and that was fundamentally achieved (Vernengo 2009). ${ }^{11}$

In that sense, the notion was that, since the Fed could not by itself get the economy out of the recession, it could help the Treasury to promote a fiscal expansion in a sustainable way. The great failure of monetary policy in this view during the $1930 \mathrm{~s}$

\footnotetext{
9 The concept of insufficient but non-redundant part of an unnecessary but sufficient condition or INUS was developed by John Mackie, and used to analyze economic causality by Hammond (1986) and (1996).

${ }^{10}$ For a history of the origins of the phrase see Vernengo 2009, p. 86.

11 This is in contradiction with the modern understanding of quantitative easing as an instrument to simply increase money supply.
} 
was not the monetary contraction, but the inability to curtail bank failures (Bernanke 1983). ${ }^{12}$

Central banks have significant power to act as lenders of last resort, and they can actually avoid widespread systemic failures of the banking system. However, their ability to control inflation, either directly through the control of the money supply, or indirectly by managing the rate of interest, has been greatly exaggerated by conventional wisdom.

\section{FISCAL POLICY, YOU SHOULD TRY IT}

The conventional theoretical macroeconomic framework, as we noted before, provides limited scope for fiscal policy as an anti-cyclical policy instrument, even if the empirical literature does show that fiscal policy is effective, particularly when the rate of interest is low (Christiano et al. 2009; Woodford 2011). ${ }^{13}$ This theoretical policy stance carries on to the empirical analysis of fiscal policy during the depression. Romer (1992) is the canonical view on the effects of macroeconomic policy during the Depression, and provides a simple formula to assess the relative influence of monetary and fiscal policies on the level of activity. According to Romer, the changes in output can be decomposed as follows:

$$
\Delta Y_{t}=\alpha_{1} \Delta M_{t-1}+\alpha_{2} \Delta\left[\frac{(T-G)}{Y}\right]_{t-1}+\varepsilon_{t}
$$

Romer (1992) infers the values of $\alpha_{1}$ and $\alpha_{2}$ by assuming that the decline in output in 1921 and 1938 were fully caused by monetary and fiscal policy, and that the residual term would be zero. The differences in the size of the coefficients are related to the

\footnotetext{
12 Another mistake that could be added is the hiking of the discount rate in 1931, after the depreciation of the pound, to avoid gold outflows. The same cannot be said of the decision to raise reserves before 1937-38 recession. As shown by Stauffer (2010) banks were able to expand credit after the increase in reserves and before the recession by switching from government securities to loans. The existence of excess reserves meant that banks were not constrained.

${ }^{13}$ In fact, by the 1990s self-styled Keynesians, such as Brad De Long (1998, p. 73) could argue that "the pre-depression fears that fiscal policy multipliers could be zero or negative were real fears."
} 
different method of estimation, to the different period, and to the fact that changes are not measured with respect to a normal period (in Romer's analysis the average level of the variables between 1923 and 1927). ${ }^{14}$ It is clear that with an increase in federal government spending from around 5 percent in the pre-depression period to close to 10 percent in the post-depression era, and Romer's fiscal multiplier of -.233, fiscal policy would be insufficient to bring the economy back from the brink of disaster. Also, state and local governments maintained surpluses during the period reducing the effectiveness of the federal fiscal stimulus.

However, the authors believe that these results and any results derived from this equation, including Romer's results, are flawed, since there are some important limitations in Romer's approach which may significantly alter the conclusions of what really brought about the recovery. The decomposition in equation (1) seems to be derived from two different identities. The first, based on the equation of exchange, says that the amount of money in circulation must be sufficient for allowing all the transactions associated with the production of output in a given year to take place.

Thus, there is a relation between output and money supply, and causality may go both ways, as noted in the previous section. The second identity comes from the National Accounts, and implies that output is decomposed into its expenditure components. From that relation a fiscal policy multiplier can be derived, presuming causality in Keynesian fashion from expenditure to income. Taxes are not usually part of the autonomous component, as in Romer's decomposition, and are incorporated in the multiplier itself.

In the monetarist tradition an increase in money supply would lead to an increase in the level of output. ${ }^{15}$ However, in the Keynesian story, money affects output indirectly through its effects on spending. In particular, as noted by Romer (1992, pp. 775-81) in her discussion of the transmission mechanism, it is the changes in the rate of interest that are essential to understanding the effects of money on income. In her specification,

\footnotetext{
${ }^{14}$ The idea of using a normal period is important to provide a measure of money supply and of the fiscal deficit that is adjusted to the changes in the economy, in other words, measures of the monetary and fiscal stance that would be independent of the cycle, sometimes incorrectly referred to as the full employment balance because neoclassical economics assumes that the normal condition is one with full utilization of resources. Then, changes from the norm would be considered to be anti-cyclical policies.

${ }^{15}$ However, when Friedman (1970) presented his model it was fundamentally an ISLM model with an augmented expectations Phillips curve. In other words, the effects of monetary policy were also intermediated by the effects of money supply on the rate of interest.
} 
however, Romer seems to believe that money affects output directly, without mediation, as in Friedman's proverbial helicopter that throws excess money that consumers can use to spend. She deals in a separate set of regressions with the role of monetary policy on the rate of interest and the latter on spending. She finds that the conventional Keynesian story holds; however, it must be noted that the issue of causality here also becomes important.

Romer's calculations presume that money supply caused changes in the rate of interest and these, in turn, led to an increase in investment and consumption. Yet again the causal relations may very well be more complex than is assumed by conventional wisdom. Money supply is only one of the influences on the rate of interest. Two other important variables that affect the rate of interest are the discount rate, a policy variable determined by the Fed, and open market operations, including quantitative easing, i.e., not just the change in the composition of the Fed's balance sheet, but also a change in its size. In other words, it is far from clear that monetary policy should be seen as fundamentally associated with the control of the money supply in that particular period.

Also, it is presumed that the lower rates of interest caused spending. The correlation between investment and interest rates is normally weak, but in this case it goes at least in the right direction. It must be noted, however, that spending falls in the periods of deflation, when the real rate of interest increases, even though the nominal rate remains constant and close to zero. It may very well be the case that the deflationary forces that reduce real wages and farmer's incomes, with the fall in agricultural prices, and lead to decreased demand also determine the increase in the real rate of interest. ${ }^{16}$ Hence, Romer's decomposition presented in equation (1) tends to confound the effects of money on income. It would be more reasonable to either provide a separate measure of the money multiplier, in which case the question of causality might be brought up, and of the spending multiplier. If one believes that the money supply is endogenous, then the more reasonable way to assess the effect of monetary policy would be by measuring the effects of the reduction of the rate of interest on spending.

In that respect, the direct impact of gold inflows, which are deemed central for the recovery in the conventional view of the Depression, on the rate of interest, seems to be

\footnotetext{
16 Note that empirical analysis of the causality between investment and output suggests that it is the latter that determines the former, as in the accelerator. See Blomström et al.1996.
} 
nil. The same can be said about the broader definition of money supply. The nominal interest rate falls from the beginning of the Depression and remains low throughout the whole period, while money supply falls up to 1933 and then grows continually all through the recovery.

The reduction in the rate of interest might have significant effects on the level of activity for different reasons. For example, the Fed was adamant that by maintaining a low rate of interest on government securities, fiscal deficits could be expanded on a sustainable basis. Hence, the importance of fiscal policy in combination with a monetary policy that facilitated fiscal expansion would be behind the expansion in spending.

Aside from the conceptual issues in Romer's multipliers that come from equation (1), there are also issues involved in the actual calculation of the multipliers. Romer's calculation, although innovative and worthy of notice, does not however produce consistent sensible multipliers. Because the calculations are so dependent on the magnitude and sign of the variables, other time periods produce completely different and often nonsensical multipliers. For instance, using the years 1923 and 1941 instead of 1921 and 1939 produces a fiscal multiplier of .25 (which has the wrong sign) and a monetary multiplier of .59. For the years 1926 and 1944, the fiscal multiplier is -.0177 and the money multiplier is .0176, far below what any historical estimate would be for each individual multiplier. Much of the problem may have to do with the lack of quarterly data available for the 1920's through WWII. Romer uses the years 1921 and 1938 because "in both cases there were large movements in real output that have been almost universally ascribed to monetary and fiscal policy decision" (Romer 1992, pg. 736). In other words, these multipliers are "narrow" multipliers that only represent these years and the information embodied in the data for these years. These calculations do not represent "broad" multipliers or the impact of government spending and monetary policy during the entire depression period through the war.

We can proceed then to look at the effects of the spending multiplier, independent of the monetary variables, assuming that investment is derived demand, according to what Hicks referred to as the supermultiplier (Bortis 1997). A simple measure of the supermultiplier would provide a quantitative estimate of the direct impact of the 
government and the external sector, the two main elements of autonomous spending, in the recovery. The supermultiplier can be represented in log-linear terms as:

$$
\Delta Y_{t}=\alpha_{1} \Delta G_{t}+\alpha_{2} \Delta X_{t}+\varepsilon_{t}
$$

In this case, $\alpha$ represents the supermultiplier, and the level of activity is determined by autonomous spending, i.e., government spending and foreign demand. Table 1 shows the results of the simple estimation, for two different specifications.

Table 1 Fiscal and Foreign Multiplier (1929-1945)

\begin{tabular}{|l|l|l|l|l|}
\hline \multicolumn{2}{|l|}{ Model 1 } & \multicolumn{1}{l|}{ Model 2 } \\
\hline Variable & $\underline{\text { coefficient }}$ & $\underline{\text { t-stat }}$ & coefficient & $\underline{\text { t-stat }}$ \\
\hline Fiscal & .4181306 & 7.06 & .2767662 & 2.90 \\
\hline Foreign & .382905 & 4.93 & .2912528 & 2.12 \\
\hline
\end{tabular}

The first model is a linear regression using the logarithm of differenced GDP as the dependent variable and the log of differenced government spending and differenced exports as the independent variables, respectively. ${ }^{17}$ Both exports and government spending are assumed to be exogenous, which provided a clean fiscal multiplier ${ }^{18}$. Exports are largely exogenous because the demand for US goods is tied to international demand for products. Using the time period 1929 through 1945, the results show a coefficient of .4181306 , which corresponds to a government spending multiplier of 1.69 . Using a similar regression and adding a lagged term to the government spending variable as well as exports to reflect the time it takes for the multiplier effect to kick in gives a slightly lower coefficient of .2767662 , implying a slightly smaller fiscal multiplier of 1.38. ${ }^{19}$ Note that the foreign trade multiplier is very similar to the fiscal multipliers (the

\footnotetext{
17 All regressions are log-linear, which means that we estimate elasticities rather than super-multipliers. For simplicity we will refer to them as multipliers, even though the presumption is that investment is derived demand.

${ }^{18}$ The potential for government spending to be endogenous is addressed in our Structural VAR model later in the paper.

${ }^{19}$ Optimal lag tests were performed using AIC criterion and results varied between 0 lags and 1 lags. The authors believe that if quarterly data were available a more optimal lag time could be found. Because the data only comes in yearly format for this time period, results for both 0 lags and 1 lag are shown.
} 
implied multiplier in model 1 is 1.62 and the implied multiplier for model 2 is 1.41), but the growth in exports during the Depression era would not be sufficient to promote an export-led recovery.

Changing the time period from 1929-1945 to 1933 to 1945 in order to capture the New Deal and the War period fiscal policies was also tested. The regression results are listed in table 2. The coefficient is .3902 in this case, implying a multiplier of 1.64, which is significantly different than the one we found by using Romer's (1992) specification.

Table 2 Fiscal and Foreign Multiplier (1933-1945)

\begin{tabular}{|l|l|l|l|l|}
\hline \multicolumn{2}{|l|}{ Model 1(no lags) } & \multicolumn{2}{l|}{$\begin{array}{l}\text { Model 2(lagged } \\
\text { independent } \\
\text { variables) }\end{array}$} \\
\hline Variable & $\underline{\text { coefficient }}$ & $\underline{\text { t-stat }}$ & $\underline{\text { coefficient }}$ & $\underline{\text { t-stat }}$ \\
\hline Fiscal & .3902853 & 5.75 & .1686379 & 1.89 \\
\hline Foreign & .3334126 & 4.93 & .0960555 & .71 \\
\hline
\end{tabular}

In order to capture the endogeneity that exists between government spending and GDP, a structural vector autoregression (SVAR) model was used to measure the fiscal and foreign trade multiplier. The identification strategy is to use the recursive approach recommended by Sims (1980). ${ }^{20}$ A triangular decomposition is used, assuming that 1) Exports are not affected by GDP or Government spending; 2) GDP is affected by both Government spending and exports; and 3) government spending is affected by GDP. This allows us to impose constraints on the matrices in the SVAR in a simplistic fashion. The ordering of the variables follows a simple narrative approach and lists them from their most exogenous (exports) to the most endogenous (GDP), with government spending listed second. ${ }^{21}$ The multiplier will be calculated using the elasticity reported from the Cholesky decomposition between the relevant variables. Optimal lag length was determined using the AIC criterion, and as expected because of the yearly data format, results indicated a lag of one year. The results of the Cholesky decomposition are listed in table 3, and estimate the SVAR for the period 1929 to 1945 and imply a government multiplier of 1.0544, and an export multiplier of 1.1502. Of all the estimations

\footnotetext{
${ }^{20}$ By imposing $\left(n^{2}-n\right) / 2$ restrictions in the structural model, the model becomes exactly identified (Enders, 2004).

${ }^{21}$ See Gordon and Krenn (2010).
} 
performed, this fiscal multiplier is the lowest. It is however, larger than Romer's estimation.

Table 3: $\operatorname{SVAR}(1929-1945)$

\begin{tabular}{|l|l|l|l|}
\hline & Foreign & Fiscal & Output \\
\hline Foreign & .13064042 & 0 & 0 \\
\hline Fiscal & -.11485823 & .13236396 & 0 \\
\hline Output & .00918903 & .05163345 & .024828 \\
\hline
\end{tabular}

Another set of models were used to calculate the fiscal multiplier, this time avoiding the endogeneity problem completely by using defense spending in place of government spending. Defense spending avoids the endogeneity problem because it is completely autonomous from GDP. The time period 1929 to 1945 was used for the standard OLS regression, and the results appear in table 4. The defense-spending coefficient is .132218 without including lagged independent variables, and .1174 with lags. This corresponds to a multiplier of 1.1523 , and 1.1330 respectively. The implied multipliers for the model with lagged independent variables are similar, for defense spending 1.13, and for exports 1.20. In particular, this suggests that different types of spending might have different multiplier effects.

Table 4 Defense Spending and Foreign Multiplier (1929-1945)

\begin{tabular}{|l|l|l|l|l|}
\hline \multicolumn{2}{|l|}{ Model 1 (no lags) } & \multicolumn{2}{l|}{$\begin{array}{l}\text { Model 2 (lagged } \\
\text { independent } \\
\text { variables) }\end{array}$} \\
\hline Variable & $\underline{\text { coefficient }}$ & $\underline{\text { t-stat }}$ & $\underline{\text { coefficient }}$ & $\underline{\text { t-stat }}$ \\
\hline Defense & .132218 & 3.36 & .1174665 & 3.02 \\
\hline Foreign & .1767485 & 1.66 & .172572 & 1.47 \\
\hline
\end{tabular}

Extending the use of defense spending as an exogenous variable, a basic Instrumental Variable (2SLS) approach was used was used to calculate the fiscal multiplier, using defense spending as an instrumental variable for government spending (see Almunia et al. 2010). This allows us to adjust for the potential endogeneity between government 
spending and GDP. Defense spending meets the criterion for use as an instrumental variable because a) it is highly correlated with government spending, and b) uncorrelated with the error term. The results are shown in table 5, and were performed with and without lags on the independent variables. The defense-spending multipliers related to the coefficient estimates are 1.62 without lags and 1.51 with lags. $^{22}$ The export multipliers increase to 1.55 and 1.51 , respectively.

Table 5 IV approach (2SLS) Fiscal and Foreign Multiplier (1929-1945)

\begin{tabular}{|l|l|l|l|l|}
\hline $\begin{array}{l}\text { Model without lags on independent } \\
\text { variables }\end{array}$ & \multicolumn{2}{l|}{ Model with Lags } \\
\hline Variable & $\underline{\text { coefficient }}$ & $\underline{\mathrm{t}-\text { stat }}$ & Coefficient & $\underline{\text { T-stat }}$ \\
\hline $\begin{array}{l}\text { Defense } \\
\text { Spending }\end{array}$ & .383165 & 5.92 & .339046 & 3.26 \\
\hline Foreign & .35532 & 4.66 & .3401905 & 2.57 \\
\hline
\end{tabular}

Finally, if one estimates the impact of the federal government's fiscal policy on employment, including the job creation programs of the New Deal, those would confirm the effectiveness of fiscal expansionism. ${ }^{23}$ The problem with the pre-1937-38 recession deficits is not that they were involuntary, which is correct, but that they were not sufficiently large for the task. Fiscal policy did not fail; it just was not tried in an adequate fashion. ${ }^{24}$ Once the recession allowed the Keynesians within the administration to dominate the policy debate, and the war made the efforts for balancing the budget a moot point, fiscal expansion was large enough to bring the economy to full employment. $^{25}$

In sum, contrary to the conventional wisdom, it seems that the New Deal and World War II, particularly through fiscal policy activism, were central for the recovery.

22 This shows conclusively that military spending is not necessarily a burden on growth (Pivetti 1992).

23 Our preliminary estimations also show multipliers that are above one. Darby (1976) provides a clear account of the effect of the New Deal on employment levels. Once the workfare programs are accounted for, unemployment fell from $25 \%$ in 1933 to $9 \%$ in 1936 , rising to $13 \%$ in 1938 , before falling to $10 \%$ in 1940 and continuously to $1.2 \%$ in 1944 . This can hardly be seen as a failure.

24 1937-38 marks the watershed between New Deal Mark I dominated by a preoccupation with regulation of monopolies and Mark II more concerned with Keynesian anti-cyclical policies. See Sandilands (2001).

${ }^{25}$ Gordon \& Krenn (2010) find that for the first quarter of 1939 to the second quarter the fiscal multiplier is 1.8, emphasizing also the importance of fiscal policy in the recovery from the Roosevelt recession of 1937-38. 
The fiscal multipliers were larger than what is assumed by conventional wisdom, and monetary policy was a subsidiary policy needed to sustain the fiscal expansion.

These results, if anything, underestimate the effects of the New Deal policies, which "left in place a set of institutional arrangements that constituted a more coherent pattern than is dreamt of in many philosophies," as one of the classic studies in the subject suggested (Kennedy 1999, p. 365). By promoting security for workers with the Wagner Act, security in old age with the Social Security Act, access to affordable housing, and other reforms that would culminate in the immediate post-war with the Employment Act in 1946, the New Deal created an environment that would prevent major crises, without the need for fiscal policy fine tuning, since the increased size of the State implied significantly larger automatic stabilizers.

\section{NEW DEAL OR NO DEAL}

The view according to which fiscal policy was not central for the recovery in the 1930s is still dominant among economists, but it was very uncommon until recently to find serious historians that would argue that the New Deal was irrelevant or even worse, detrimental for the economy, and that it delayed the upturn (e.g. Shlaes 2007; Folsom 2008). These positions, however, have been fueled by the research of New Keynesian authors that suggest that "fiscal policy ... contributed almost nothing to the recovery before 1942" (Romer 1992, p. 781), and by the notion raised "by economists working in the Keynesian tradition ... that deficit spending is not expansionary" (De Long 1998, p. 72).

In the extreme, this view led to a complete denial of the relevance of fiscal activism. Again De Long (1998, p. 84), now a defender of fiscal policy to counteract the so-called Great Contraction, argued: "do not attempt to aggressively use discretionary fiscal policy because the lags make it impossible to do so in an effective manner." The New Deal without fiscal policy activism, which was the result of a hard won intellectual battle within the corridors of power, or the successful employment programs, would be like Hamlet without the Prince.

By denying incorrectly the importance of fiscal policy, and incorrectly emphasizing the effects of monetary policy, the revisionist view diminishes the 
accomplishments of the New Deal, and promotes the anti-New Deal agenda of the conservative movement. As correctly noted by Hannsgen and Papadimitriou (2009) the New Deal revisionism is central to understanding the current ascendancy of fiscal policy skepticism. Contrary to De Santayana, in this case those who cannot remember the past (or prefer to distort it) are condemned to not repeat it. 


\section{REFERENCES}

Almunia, M., A. Benetrix, B. Eichengreen, K. O'Rourke, and G. Rua. 2010. "From Great Depression to Great Credit Crisis: Similarities, Differences and Lessons." Economic Policy, Vol. 25, Issue 62, pp. 219-265, April.

Amadeo, E. 1989. Keynes’ Principle of Effective Demand. Aldershot: Edward Elgar.

Bernanke, B. 1983. "Non-monetary effects of the financial crisis in the propagation of the Great Depression." American Economic Review, 73, pp. 257-76.

Blomström, M., R. Lipsey, and M. Zejan. 19961. "Is Fixed Investment the Key to Economic Growth?" Quarterly Journal of Economics, 111(1), February, pp. 26976.

Bordo, M. and F. Kydland. 1996. "The Gold Standard as a Commitment Mechanism," in T. Bayoumi, B. Eichengreen, \& M. Taylor (eds.), Modern Perspectives on the Gold Standard. New York: Cambridge University Press.

Bortis, H. 1997. Institutions, Behaviour and Economic Theory. Cambridge: Cambridge University Press.

Brown, E. C. 1956. "Fiscal Policy in the Thirties." American Economic Review, 56, pp. 857-79.

Christiano, L., R. Motto, and M. Rostagno. 2003. "The Great Depression and the Friedman-Schwartz hypothesis." Proceedings, Federal Reserve Bank of Cleveland, pp. 1119-1215.

Christiano, L., M. Eichenbaum, and S. Rebelo. 2009. "When is the Government Spending Multiplier Large?” NBER Working Paper No. 15394.

Darby, M. 1976. “Three and a half million US employees have been mislaid." Journal of Political Economy, 84(1), pp. 1-16.

De Long, B. 1998. "Fiscal policy in the shadow of the Great Depression," in M. Bordo, C. Goldin and E. White (eds.), The Defining Moment: The Great Depression and the American Economy in the Twentieth Century. Chicago: University of Chicago Press.

Diaz Alejandro, C. 1984. "Latin America in the 1930s," in R. Thorp (ed.), Latin American in the 1930s: The Role of the Periphery in World Crisis. New York: St. Martin's Press, pp. 17-49.

Eichengreen, B. 1992. Globalizing Capital. Princeton: Princeton University Press. 
Eichengreen, B. 1996. Golden Fetters. New York: Oxford University Press.

Eichengreen, B. and J. Sachs. 1985. "Exchange rates and economic recovery in the 1930s." Journal of Economic History, 45, pp. 925-46.

Enders, W. 2004. Applied Econometric Time Series. New Jersey: John Wiley and Sons.

Friedman, M. 1970. "A theoretical framework for monetary analysis." Journal of Political Economy, 78(2), pp. 193-238.

Friedman, M. and A. Schwartz. 1963. A Monetary History of the United States, 18671960. Princeton: Princeton University Press.

Folsom, Jr., B. W. 2008. New Deal or Raw Deal? New York: Simon \& Schuster.

Gordon, R. and R. Krenn. 2010. "The end of the Great Depression, 1939-41.” National Bureau of Economic Research Working Paper No. 16380.

Hammond, J. D. 1986. "Monetarist and Anti-monetarist Causality," in W. J. Samuels (ed.), Research in the History of Economic Thought and Methodology, JAI Press, pp. 109-26.

Hammond, J. D. 1996. Theory and Measurement: Causality Issues in Milton Friedman's Monetary Economics. Cambridge and New York: Cambridge University Press.

Hannsgen, G. and D. Papadimitriou. 2009. "Fiscal Stimulus, Job Creation and the Economy: What Are the Lessons of the New Deal? Policy Note No. 2009/10. Annandale-on-Hudson, NY: Levy Economics Institute.

Kennedy, D. M. .1999. Freedom from Fear. New York: Oxford University Press.

Kindleberger, C. P. 1973. The World in Depression. Berkeley: California University Press.

Meltzer, A. 2003. A History of the Federal Reserve. Chicago: Chicago University Press.

Pivetti M. 1992. An Essay on Money and Distribution. London: Macmillan.

Romer, C. 1992. "What ended the Great Depression?" Journal of Economic History, 52(4), pp. 757-84.

Sandilands, R. 2001. "The New Deal and 'Domesticated Keynesianism' in America," in M. Keaney (ed.), Economist with a Public Purpose: Essays in Honor of John Kenneth Galbraith. New York: Routledge.

Sims, C.A. 1980. "Macroeconomics and Reality." Econometrica, 48, 1-48. 
Shlaes, A. 2007. The Forgotten Man. New York: Harper Collins.

Stauffer, R. 2010. "Federal Reserve policy and the recession of 1937-1938." Journal of Post Keynesian Economics, 32(4), pp. 591-600.

Temin, P. 1989. Lessons from the Great Depression. Cambridge: MIT Press.

Vernengo, M. 2009. “A hands-off central banker?” In R. Leeson (ed.), American Power and Policy. London: Palgrave-Macmillan, pp. 91-104.

Woodford, M. 2011. "Simple Analytics of the Government Expenditure Multiplier." American Economic Journal: Macroeconomics, 3(1), pp. 1-35. 